\title{
Normansfield: Vacuum of management in the NHS
}

\author{
RUDOLF KLEIN
}

Perhaps the most extraordinary, and certainly the most disquieting, revelation offered by the Report of the Committee of Inquiry into Normansfield Hospital ${ }^{1}$ is that of a breakdown in the NHS's system of management. The vocabulary of management-with its emphasis on monitoring and accountability-is shown to have been empty, incantatory rhetoric devoid of substance. The report convincingly demonstrates that if the situation at Normansfield had indeed been monitored effectively, if there had been a determination to make those concerned accountable for their actions and policies, the explosion which precipitated the inquiry would never have happened. Some of the circumstances leading to the crisis were indeed unique to Normansfield, while others derive from the special problems inherent in caring for the mentally handicapped. But many of the more fundamental weaknesses in the system of management follow, as I shall try to show, a pattern already evident in previous inquiries. The report therefore has some uncomfortable implications which go beyond this particular case-or indeed the field of mental handicap-and which are highly relevant for any future changes in the NHS's organisation.

The strike which prompted the inquiry occurred in May 1976. This is when the nursing staff walked out, deserting their patients, so as to draw attention to their grievances against the consultant psychiatrist, Dr Terence Lawlor. But this was no sudden or unpredictable eruption, but rather the culmination of a long chain of events. The fact that the situation at Normansfield had turned sour-and that the quality of patient care had deteriorated scandalously as a result - had long been known at all levels of the NHS's hierarchy of management. If ever there was a preventable explosion this was it: to sum up the message of the report, this was the story of a train approaching a precipice with everybody concerned sitting on their hands, hoping that the worst would not happen.

The report sets out some of the main incidents in the history of Normansfield. As early as 1972, Dr Lawlor was interviewed by "three wise men," following disagreements between him and some of his medical colleagues. Their conclusion was that "there has been a breakdown of the normal professional relationship." In 1974 there followed a spate of resignations from the staff, a letter from the community health council to the area health authority expressing concern about standards of treatment, and a complaint from the chief nursing officer at Normansfield about Dr Lawlor's "interference in nursing matters"-so signalling the breakdown of the relationship between the consultant and the nursing staff which was at the root of much of the trouble. The same year a member of the regional health authority, Dr Ivan Clout, visited the hospital and, alarmed by what he saw, described it as a "time bomb." In 1975 the CHC repeated its concern, further evidence of ill feeling between Dr Lawlor and the nursing staff was drawn to the attention of the AHA team of officers, and evidence of poor conditions continued to accumulate. In particular, a nursing officer from the DHSS reported, after visiting the hospital, "I was greatly concerned that management was failing in its duty

University of Bath

RUDOLF KLEIN, MA, professor of social policy to patients here, and that in addition a serious embarrassment to Ministers might occur if there were further deterioration in standards of care."

\section{No lack of information}

So there was no lack of information about what was happening at Normansfield. Everybody concerned, at all levels, was well aware that, to quote the report, "the standard of nursing care was generally extremely low and the quality of life of many of the patients suffered accordingly." Morale was low and, in the inquiry's view, "Dr Lawlor made the very worst of an already poor situation." While there may have been scope for disagreement about allocating personal responsibility for the circumstances at Normansfield, there was no scope for doubt that incompatibility and hostility between the individuals concerned was damaging the interests of patients. Yet nothing was done. While shortage of staff and decaying buildings (the depressingly familiar story when it comes to hospitals for the mentally handicapped) contributed to Normansfield's deplorable state, the report by Michael Sherrard and his colleagues concludes that these were not the "principal cause of difficulty." The final verdict is that the conditions at Normansfield reflected a "failure of duty by the area health authority (and in particular the area management team)." In turn, the regional health authority "failed adequately to monitor the work of the area health authority.'

The report is scathing about many of the individual officers concerned at the different management levels. In particular, the medical, nursing, and administrative members of the AMT come under criticism; only the treasurer is explicitly exempted. Of one medical member, the report says that his "advocacy of a policy of inactivity was in large part responsible for the underlying failure of the area management team as a whole to deal with the problems of Dr Lawler." Of another, it says "he appeared by nature cautious, pedantic and defensive . . . his philosophy was one of non-involvement." Furthermore, these comments are in addition to the well-publicised conclusion that the area administrator "is not competent to hold the very responsible post he occupies." Indeed, this inquiry's report is unprecedented in its comprehensive willingness to recommend the dismissal of various members of staff whose performance was, in the view of the inquiry committee's members, inadequate.

One possible conclusion to draw from all this is that Kingston and Richmond AHA was singularly unfortunate in the quality of staff that it attracted: that, by some mischance, it managed to recruit a disproportionate number of rather passive administrators, medical, nursing, and lay. If so, no general conclusions for the NHS as a whole can be drawn from the report about the quality of management. But the Normansfield Report is not the first to be critical of the way in which area teams of officers work. In the case of the inquiry into the affairs of Solihull AHA ${ }^{2}$ the report found that the team had "completely and irremediably broken down" because of quarrels among its members. In the case of the inquiry into the affairs of Rochdale AHA the report criticised the effectiveness of the team, although making no criticism of individual members. So, while it is impossible to assess the general quality of NHS management on the basis of 
the Normansfield inquiry, it cannot be dismissed entirely as an eccentric, totally atypical instance.

\section{“Consensus management did not work"}

Furthermore, it is important to distinguish between the quality of individual managers and the effect of the environment in which they work. In his foreword to the report, $\mathrm{Mr}$ David Ennals, Secretary of State for Social Services, cites Normansfield as showing that, in this particular instance, "the present system of consensus management did not work effectively." But it is possible to derive an even more serious criticism from the report. Conceivably passivity may be the occupational disease of consensus team members: in other words, unanimity may be easiest to achieve when the decision is to do nothing. Moreover, one interpretation of the Normansfield saga could be that when everyone is responsible for all decisions, no one feels any particular obligation to take the lead in assuming responsibility for handling any particular problem. Avoidance of confrontations may become the dominant philosophy. Once again, it would be a mistake to generalise too recklessly from the case of Normansfield, but at the very least it carriss a warning that-irrespective of the quality of individual managers-the present system may be biased towards encouraging passivity, until action becomes inevitable in a crisis situation, rather than pre-emptive action and the assumption of positive leadership.

More specifically, the Sherrard inquiry criticises the handling by both regional and area officers of the events immediately before the strike in May 1976. No one emerges well from this episode. The report documents "a series of blunders" by officers of the Confederation of Health Service Employees, some of whom are described as "coarse opportunists who embraced the discontent as an ally in demonstrating their trade union muscle." Similarly, the health authorities ignored a series of warning signals. In particular, the area management tcam "adopted an approach which was both casual and complacent," so leaving the nursing staff "with the impression that their complaints were not being taken seriously or with anxiety." This would suggest a quite specific weakness in NHS management-the lack of adequately trained capacity to deal with industrial relations. Again, Normansfield is not an isolated example: the inquiry into the conduct of industrial relations in Liverpool AHA ${ }^{4}$ amply documented this failure. Given increasingly militant unions, often competing with each other for members and frequently unable or unwilling to control their rank and file, this is likely to become a growing source of managerial mistakes. So in this respect the Normansfield inquiry would seem to point up the need for a change in national policies.

The Normansfield Report carries a further, perhaps more controversial, implication for national policy. For in one crucial respect the experience of Normansfield reflects a more general problem: the difficulty of moving people from their posts once they are established. This difficulty is not limited to the NHS: it is equally apparent in the universities, where academics, once they achieve tenure, have virtual guarantee of a job for life. Nor, within the NHS, is the job security of consultants alleged by the RHA chairman, Lady Robson, ${ }^{5}$ exclusive to that group of staff. Effectively, if not contractually, most NHS employees tend to have tenure for life-since dispossessing them is, if not impossible, time-consuming, disputatious, and difficult.

In many ways this is an admirable development. For most people their job is also their most important property right. For academics and doctors security is, additionally, a safeguard of their independence and professional integrity. There is, however, a heavy cost to be paid. Even if there are established procedures for getting rid of people who are demonstrably incompetent this does not deal with the rather different situation which may arise in cases of incompatibility between colleagues or unsuitability for a particular post. The Normansfield inquiry is rich in examples of both: much of the trouble at the hospital arose out of a combination of clashing personalities and a mismatch between the demands of the jobs concerned and the abilities of their occupants. But, once again, it is important to stress that Normansfield was not unique. The Solihull inquiry, already cited, ${ }^{2}$ demonstrated that problems arise when the members of a management team fall out among themselves-when there is what would be called in the divorce courts an irretrievable breakdown in personal relations.

Unfortunately, unlike the divorce courts the NHS does not appear to have adequate machinery for dealing with this kind of breakdown. The Health Services authorities can seek to dismiss unsatisfactory employees but they lack procedures for moving people from one job to another without inflicting major hurts on them. A mistake once made, in terms of fitting people to jobs appropriate to their abilities, tends to become permanent. In contrast, the Civil Service, while offering at least as much security as the NHS, has considerable scope for moving people around. When I once professed my amazement at the promotion of an obviously incompetent administrator to an undersecretaryship I was gently told that he could do far less damage in his new post than in his previous one.

\section{NHS as a national employer?}

One conclusion to draw from this might be that the NHS should move towards being a national employer: that consultants, administrators, nurses, and others should be employed not by a particular health authority but by the NHS. In short, they should be guaranteed a particular kind of job, not life occupancy of a specific post. In such circumstances, it would be relatively easy and much less painful to prevent more Normansfield- or Solihull-type breakdowns from arising by moving the people concerned. The case for such a change may be especially strong in the particular circumstances of mental handicap hospitals, where professional isolation may reinforce the problems that stem from personality clashes. But there would be obvious attractions about increasing the opportunities for mobility more generally in a period of slow expansion, when life occupancy can all too easily also become a life sentence to what may become an increasingly stale routine. I am tempted to argue that no consultant-or university professor for that matter-should hold his or her post for more than 10 years before moving on. There are obvious problems about such a proposal-for example, the costs (social as much as financial) of moving. Nevertheless, in the absence of policies designed to encourage flexibility and mobility the NHS may increasingly suffer from what is already one of the ills of British society: a sclerotic caste system based not so much on social classes but on occupational categories granting job rights.

The final conclusion for national policy which I draw from the Normansfield Report is less clear-cut and rather more in the nature of a perplexed question about the scope for "democratic" control in the NHS. The discussion so far, reflecting the balance of the report, has been mainly about the roles of service providers and administrative officers at different levels. But the chain of accountability for the services provided to the public, for which the Secretary of State is answerable to Parliament, runs through the area health authority. The area management team is accountable to the members of the authority, while, in turn, the authority is collectively accountable for all the services provided to the RHA. In turn, the RHA is accountable to the Secretary of State. So, if the buck for what happened at Normansfield stops anywhere, it is with the members of Kingston and Richmond AHA. It is the AHA which "is responsible for the state of affairs we find to have existed at Normansfield," in the words of the report. In the event, the members of the AHA did not-so far as can be judged from the report-play any part whatsoever in the history of Normansfield. Here was the real vacuum in the management of the NHS. They failed to monitor the activities of their team of officers; they seem to have ignored the warning noises coming from the $\mathrm{CHC}$ and other quarters. The report 
prints, deadpan, the following exchange during the hearings with the chairman of the AHA (who was not reappointed when his term of office expired in 1977):

"Q. Do you think that the area management team handled the Normansfield situation in a way that is beyond criticism between 1974 and March 1976 ?

A. Yes, I do."

\section{Not an isolated instance}

What makes the failure of Kingston and Richmond AHA so disquieting is that, once again, this is not an isolated instance. Indeed, it has a long lineage. As long ago as 1969 the report on the Committee of Inquiry into conditions at Ely ${ }^{6}$ - which first drew attention to the plight of hospitals for the mentally handicapped-criticised the hospital management committee for not playing a more active part. Similar criticisms were made by the Farleigh $^{7}$ and Whittingham ${ }^{8}$ inquiries. One reason for this, the Ely report argued, was that HMC members found it difficult to combine the role of consumer representatives with that of management. Whether or not as a direct result of this argument, the 1974 reorganisation separated the representative and managerial tasks, the former going to $\mathrm{CHCs}$, and the latter being allocated to the AHAs. But the available evidence hardly suggests that AHAs are more effective than HMCs. The Liverpool inquiry ${ }^{4}$ showed that authority members had a poor attendance record and showed a lack of interest in the major problem facing the area-industrial relations. The Rochdale inquiry ${ }^{3}$ concluded that "the area health authority and the chairman of the authority must, as a matter of urgency, take steps to provide the degree of leadership which their staff-and the public-are entitled to expect from them." Indeed, in the long list of inquiries which span the period both before and after the 1974 reorganisation it is difficult to find a single instance where the members of the relevant HMCs or authorities emerge with credit.

It may be argued that, by definition, those authorities which are the subject of inquiries will be unrepresentative. Indeed, it would be quite wrong to conclude that the failures revealed at Normansfield and elsewhere are general. The importance of such inquiries is rather different. They point to the potential sources of weakness in the NHS. In the case of the AHAs the evidence may indicate that there may be a tension between the principles of responsibility and representativeness. How can AHA members be held accountable in their managerial role to the region (and indirectly to the Secretary of State) while also being accountable in their representative role? The Grey Book ${ }^{8}$ may exhort them to forget that they are representatives. But in practice members may not be able to manage such a divided self. Furthermore, how in the last resort can members of the AHA be held responsible for their mistakes when they are nominated or elected by local authorities, professional bodies, and trade unions ? Significantly, Mr Ennals has not called on the members of Kingston and Richmond AHA to resign-though that would be the logical outcome of the Sherrard inquiry. The reason is, presumably, that he cannot do so without appearing to be infringing the rights of the nominating bodies.

Conceivably, AHAs may disappear if the Royal Commission on the NHS recommends a simplification of the organisation; certainly the present Government seems poised to axe them, given the necessary cue. But this will not dispose of the problems of management illustrated by the Normansfield inquiry: precisely the same kind of difficulties will arise if there are, say, district health authorities (which Kingston and Richmond effectively is already, since it is a single-district AHA). Three questions, therefore, need answering before any further changes are made. Firstly, what should be the balance between the managerial and representative principles in the selection of members ? Secondly, can the members of authorities, however selected, be expected to play their part without adequate training ? Thirdly, can they be expected to monitor the performance of their officers without access to independent advice?
Any move towards a more decentralised NHS will largely depend on whether or not it is possible to devise answers to such questions and so to develop a more effective system of accountability than that shown by the Normansfield inquiry. For, while doubts remain about the effectiveness of the members of authorities, the DHSS will inevitably, and probably rightly, continue to insist on exercising a close control over what happens at the coalface of the NHS.

\section{References}

${ }^{1}$ Report of the Committee of Inquiry into Normansfield Hospital. London, DHSS, 1978 (to be published by HMSO).

${ }^{2}$ Report of the Tribunal of Inquiry held in February and March 1977, West Midlands Regional Health Authority, 16 May, 1978.

${ }^{3}$ The Organisation and Management of the Health Service in the Rochdale Area: Report of the Special Committee, North Western Regional Health Authority, September 1976.

${ }^{4}$ Report of a Committee of Inquiry, Mersey Regional Health Authority, January 1978.

5 British Medical fournal, 1978, 2, 1580.

${ }^{6}$ Report of the Committee of Inquiry into Allegations of Ill-treatment of Patients and Other Irregularities at the Ely Hospital, Cardiff, Cmnd 3975. London, HMSO, 1969.

${ }^{7}$ Report of the Farleigh Hospital Committee of Inquiry, Cmnd 4557. London, HMSO, 1971.

${ }^{8}$ Report of the Committee of Inquiry into Whittingham Hospital, Cmnd 4861. London, HMSO 1972.

${ }^{9}$ Management Arrangements for the Reorganised National Health Service. London, HMSO, 1972.

\section{BMA Congress, Hong Kong-continued}

to 26 days' duration, all of which include accommodation at either the Excelsior or Mandarin Hotel in Hong Kong for the congress. Prices range from $£ 435$ for 13 days in Hong Kong ( $₫ 367$ for travel only without hotel accommodation) to $£, 1155$ for 26 days' tour, including 16 days in the People's Republic of China. These charges are per person based on sharing a twinbedded room with bath and continental breakfast. Single room supplements vary from $£ 130$ to $£ 293$. All meals are included in the itineraries to China; the numbers for these are strictly limited.

Other tours include Singapore, Hong Kong, and Bangkok (19 days for 6635 ); and Tokyo (for IXth FIGO Congress) and Hong Kong (19 days for $£ 795$ ). Full details are available in the tours brochure available from the BMA or direct from John Hobbs, specialised travel manager, Turnbull Gibson Travel, Matheson House, 142 Minories, London EC3N 1QL (tel 01-488 4646).

The congress will be held in the height of the tourist season in Hong Kong when there is a demand for hotel accommodation. Early application is advised for all tours. To facilitate attendance at the congress, members are recommended to make all travel arrangements through the official agent.

Autumn is the best season in Hong Kong. The average temperature is $23^{\circ} \mathrm{C}\left(74^{\circ} \mathrm{F}\right)$ and the humidity $73 \%$. There are normally seven or eight hours of sunshine daily.

\section{Other medical conferences in the Far East}

The IXth World Congress of Gynaecology and Obstetrics FIGO will be held in Tokyo from 25 to 31 October 1979. Further details can be obtained from Dr J S Tomkinson, secretary general, 27 Sussex Place, Regent's Park, London NW1 4RG.

The IIIrd Asian-Oceanian Congress of Radiology will take place in Singapore from 28 October to 3 November 1979. Further details can be obtained from the congress secretariat, 3rd AOCR, c/o Department of Diagnostic Radiology, Singapore General Hospital, Singapore 3. 